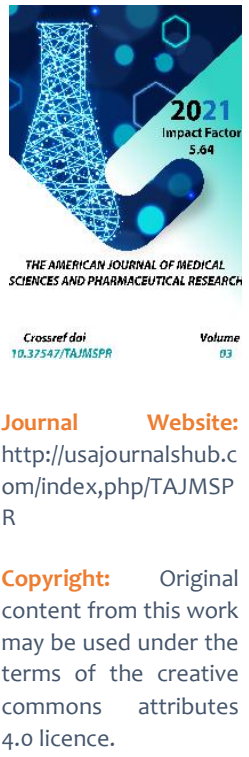

\title{
The Risk Of Developing Anemia In Patients With Chronic Heart Failure And Its Prognostic Value
}

Akhmedova N.Sh.

Bukhara State Medical Institute, Uzbekistan

Abdullaeva U.K.

Bukhara State Medical Institute, Uzbekistan

Kushaeva N.B.

Bukhara State Medical Institute, Uzbekistan

\section{ABSTRACT}

Analysis of modern views on the problem of anemia in chronic heart failure (CHF), on the main pathogenetic mechanisms of its formation and the possibility of drug correction. The CHF problem has a number of interdisciplinary aspects. One of the pathologies often encountered in CHF is anemia, which aggravates hemodynamic disturbances and worsens the prognosis in patients. Understanding the mechanisms of the development of anemia in CHF is of great importance for the choice of treatment tactics. The review discusses the views on the pathogenetic mechanisms of the formation of anemic syndrome in patients with CHF. The approaches to its treatment from the point of view of pathogenesis are considered. Anemia in $\mathrm{CHF}$ is associated with an increased risk of death, worsening of the course of concomitant diseases and an increase in the functional class of heart failure, but it is a potentially reversible condition.

\section{KEYWORDS}

Chronic heart failure, anemia, cardiorenal anemic syndrome

\section{INTRODUCTION}

In recent decades, there has been a continuous increase in the number of people with chronic heart failure (CHF) [1]. This is due to an increase in the proportion of older age groups among the population, as well as an increase in the survival rate of patients with cardiovascular 
diseases as a result of improved medical care [1].

$\mathrm{CHF}$ is not an exclusively cardiological problem; the disease has a number of interdisciplinary aspects. Therefore, an important task in the treatment of such patients is the timely diagnosis and correction of conditions that aggravate the severity of heart failure. One of them is anemia.

The purpose of this review is to analyze modern views on the problem of anemia in chronic heart failure, on the main pathogenetic mechanisms of its formation and the possibility of drug correction.

\section{MATERIAL AND METHODS}

Anemic syndrome is quite common in patients with CHF. According to numerous clinical studies (SOLVD, ELITE II, ValHeFT, COPERNICUS, COMET), anemia occurs in 7-79\% of people with heart failure [2]. A significant scatter in its prevalence rates is explained by the lack of a unified approach to the diagnosis of anemias, the heterogeneity of their causes, differences in the severity of $\mathrm{CHF}$, in the demographic data of patients, as well as comorbidity in the subjects. It has been noticed that the prevalence of anemia increases with the severity of heart failure $[3,4]$. It was more often detected in elderly patients [5]. There is evidence of a greater incidence of anemia in women with $\mathrm{CHF}$ [6]. At the same time, it was noticed that among young people it develops more often in women, while over the age of 85 - in men. Thus, in the age group over 85 years old, anemia was registered in men in $27-40 \%$ of cases, and among women - only in 16-21\% [7].

\section{RESULTS}

Researchers recognize the negative contribution of anemia to the clinical picture, course, rate of progression of $\mathrm{CHF}$ and even consider it an independent predictor of death.
There is evidence that the clinical picture in patients with $\mathrm{CHF}$ with anemia is characterized by aggravation of systolic and diastolic dysfunction of the heart, an increase in the functional class (FC) of $\mathrm{CHF}$, a rapid rate of decline in renal function, a deterioration in the quality of life and a low BMI [8,9]. However, some authors still do not find a reliable relationship between anemia and the state of the cardiac output fraction [10].

The Framingham study was one of the first to demonstrate that anemia is an important risk factor in people with CHF [11]. And the results of the SOLVD study showed a negative inverse relationship between the hematocrit level and mortality in CHF. So, for 33 months of observation, the mortality of patients was $22 \%$, $27 \%$ and $34 \%$ for hematocrit $40-44 \%, 35-39 \%$ and less than $35 \%$, respectively [12].

D. Silverberg noted that with a $1 \%$ decrease in hematocrit, the risk of death in patients with CHF III - IV FC increases by 11\% [13]. And according to a 3-year follow-up of Italian researchers, mortality from cardiac causes among people with CHF and anemia exceeded that in patients without anemia and more often led to the development of severe coronary events (39\% and $27 \%$, respectively) [14]. A relationship was found between the presence of anemia in patients with $\mathrm{CHF}$, the frequency of hospitalizations for its decompensation, and the cost of treatment. According to the analysis of 91,316 case histories of persons hospitalized due to CHF decompensation, anemia turned out to be a stronger predictor of the need for early readmission than ischemic heart disease with surgical repair of coronary arteries or arterial hypertension [15].

Most patients with CHF are characterized by a mild course of anemia. Taking into account the unity of some pathogenetic mechanisms of anemia and $\mathrm{CHF}$, it is advisable to assume the 
progression of anemia with an increase in the degree of $\mathrm{CHF}$ decompensation. This pattern has been shown in a number of studies. At the same time, it is rarely noted that anemia reaches a moderate or severe degree, more often it is about a greater occurrence of mild anemia with an increase in the severity and FC of CHF [16].

Judging by the literature data, it is the pathogenetically associated anemia that has arisen as a consequence of the negative effect on the course of heart failure. Research by P.R. Carla, which included patients with recent heart failure, which could not yet lead to anemia $(n=552)$, showed that the prognosis of the disease does not depend on the presence of a decrease in hemoglobin [17].

To date, the pathogenesis of anemic syndrome in patients with CHF is not fully understood. Among the mechanisms underlying the development of anemia are impaired renal function, hemodilution, iatrogenic factors (the use of angiotensin-converting enzyme inhibitors (ACE inhibitors), angiotensin II receptor blockers (ARBs), beta-blockers (BAB), acetylsalicylic acid), the effect of proinflammatory cytokines malabsorption syndrome. In addition, there is a direct inhibition of the bone marrow due to its hypoperfusion in violation of the pumping function of the heart [10].

The mechanisms of decreasing the hemoglobin level in patients with CHF can be conditionally divided into two categories: leading to anemia of chronic disease (ACD) (cardiorenal anemic syndrome, the effect of pro-inflammatory cytokines) and contributing to the development of iron deficiency (exposure to drugs, malabsorption syndrome, cardiac cachexia). The proportion of these mechanisms in patients with $\mathrm{CHF}$ is not the same.
When considering the causes of anemic syndrome among patients with $\mathrm{CHF}$, the authors note a different structure of anemia. A large Canadian study on the epidemiology of anemic syndrome in CHF $(n=12,065)$ showed the prevalence of iron deficiency anemia (IDA) - $58 \%$. In $27 \%$ of cases, B12-deficiency anemia was detected, in $8 \%$ - folate deficiency, and only $7 \%$ of cases had signs of ACD without iron deficiency [18].

J. Ezekowitz et al. describe iron deficiency as the cause of anemia in $21 \%$ of patients, deficiency of other hematopoietic factors - in $8 \%$ AChD and other specified forms of anemia figured in the diagnosis in $58 \%$ and $13 \%$ of patients, respectively [18].

According to domestic and Ukrainian scientists, in $24-40 \%$ of patients anemia was regarded as iron deficiency, in $4-7 \%$ - as B12deficient, in $4-11 \%$ of patients there were other specified causes of anemia. In 46-69\% of patients, anemia was not specified, but it met the criteria for AChD $[5,19]$. According to G.P. Arutyunov with $\mathrm{CHF}$, about $50 \%$ of anemias can be regarded as $A C D$ [20].

ACD most often has a normochromic normocytic character, less often it can be moderately hypochromic or hypochromicnormocytic. The level of reticulocytes is normal or reduced. Bone marrow is characterized by a normal or reduced number of erythrokaryocytes, macrophages with hemosiderin inclusions, and a high content of sideroblasts. There is also a moderate decrease in the level of serum iron or its normal content (10-18 $\mathrm{mg} / \mathrm{L}$ ), a decrease in the values of the total iron-binding capacity of serum, transferrin, saturation of transferrin with iron $(<20 \%)$ and an increase or normal level of ferritin (40-300 $\mu \mathrm{g} / \mathrm{L})$ ), i.e. there is a redistributive (functional) iron deficiency. In other words, the indicators of iron metabolism in ACD can vary over a fairly wide range [21]. 
According to the literature, in most patients with $A C D$, the level of hepcidin is elevated [21]. Hepcidin is an acute phase protein with the properties of a universal humoral negative regulator of iron metabolism in the body, blocking the expression of the ferroportin protein on the membrane of iron depot cells (enterocytes, hepatocytes, macrophages) [22]. Ferroportin is responsible for the transport of iron from the cell into the blood - a decrease in its content contributes to a decrease in the release of iron from the depot and the development of hypoferremia. Hepcidin synthesis is enhanced by inflammation and iron overload conditions. Thus, in ACD, the total biological effects of hepcidin are aimed at reducing the amount of iron due to a decrease in iron absorption in the small intestine and due to its sequestration in macrophages and hepatocytes [23].

IDA has a microcytic hypochromic character, the indicators of iron metabolites are reduced (serum iron $\leq 10 \mu \mathrm{mol} / \mathrm{L}$, serum ferritin $\leq 14 \mu \mathrm{g}$ $(\mathrm{L})$, the level of transferrin is increased, there is a reduced percentage of transferrin saturation with iron and increased concentrations of soluble serum transferrin receptors. In most cases, the content of hepcidin during IDA is reduced $-20-25 \mathrm{pg} / \mathrm{ml}$ [24].

In patients with $\mathrm{CHF}$, there is often a combination of ACD and IDA. In such patients, there is a moderate decrease in the levels of serum iron, transferrin and saturation of transferrin with iron, the content of serum ferritin is moderately reduced or within the normal range, the concentration of soluble receptors is moderately increased or normal. Differential diagnosis of these conditions is of fundamental practical importance: it determines the adequate therapeutic tactics and avoids the prescription of iron preparations to patients with a possible overload and the risk of developing secondary hemosiderosis [25].
According to various sources, iron deficiency is determined in $5-42 \%$ of patients with $\mathrm{CHF}$ [27]. The pathophysiological prerequisites for this are malabsorption syndrome, cardiac cachexia associated with compensatory hypodynamia and malnutrition, as well as latent gastrointestinal bleeding (GIT) caused by the intake of acetylsalicylic acid, and even proteinuria [16].

Among patients with $\mathrm{CHF}$ with anemia, there is both absolute and relative (functional, redistributive) iron deficiency. With functional deficiency, iron becomes unavailable for erythropoiesis even at its normal level, since it is located in the macrophage depot; this condition is typical for AChZ [2]. As the disease progresses, cells in the bone marrow continue to consume iron for their own needs. As a result, the plasma pool of iron is depleted, which, against the background of a violation of its absorption in enterocytes, causes hypoferremia [26]. This explains the fact that as the severity of anemia in CHF increases, the combination of ACD and IDA is more common, and a category of patients with isolated IDA appears [3, 27].

In addition, there is a group of CHF patients with a reduced serum iron content, but with a normal hemoglobin level (latent iron deficiency). According to the literature, this group is about $32 \%$ [28]. Multivariate regression studies have shown that patients with normal hemoglobin levels but low serum iron levels have lower quality of life on the HRQoL (Health-Related Quality of Life) scale than in a comparable group of patients. without iron deficiency [29]. Reduced serum iron in the absence of anemia is an independent factor that determines the level of submaximal exercise in patients with CHF [30]. Thus, a normal hemoglobin level does not exclude iron deficiency; this condition should be detected in all patients with $\mathrm{CHF}$ for timely medical correction. 
Given the significance of the negative contribution of anemia described in this review to the prognosis in $\mathrm{CHF}$, the need for its correction is beyond doubt. But today there is no unified strategy for treating anemia in patients with CHF. The variety of etiopathogenetic mechanisms of the formation of anemic syndrome in these patients complicates the choice of treatment tactics. The existing approaches to the treatment of anemic syndrome in $\mathrm{CHF}$ are more associated with ACD and IDA, as well as with their combination.

The objectives of medical correction of anemic syndrome in patients with $\mathrm{CHF}$ are to reduce the risk of fatal events, improve prognosis, reduce the need for diuretics, reduce the frequency of hospitalizations and improve the quality of life [20].

\section{CONCLUSION}

Summarizing the above, we can state that anemia in chronic heart failure (CHF) is common and has important clinical and prognostic significance. At the same time, the pathogenetic mechanisms of its development are diverse and have not been fully studied; to date, the ways of drug correction of anemic syndrome in CHF have not been clearly defined. All this determines the relevance of research in this direction.

\section{REFERENCES}

1. Ponikowski P., Voors A.A., Anker S.D., Bueno H., Cleland J.G.F., Coats A.J. S. et al. Rekomendatsii ESK po diagnostike i lecheniyu ostroi i khronicheskoi serdechnoi nedostatochnosti 2016. Ros. kardiol. zhurn. 2017; 1(141): 7-81. (in Russian)

2. Solomakhina N.I., Nakhodnova E.S., Ershov V.I. Anemiya pri khronicheskoi serdechnoi nedostatochnosti: rol' gepsidina kak universal'nogo regulyatora metabolizma zheleza. Zhurn.
Nedostatochnost'. 2014; 85(4): 254-60. (in Russian)]

3. Marazia S., Loderini S., Magliari F., Sarullo F.M., Di Mauro M. Sucrosomial iron supplementation can be a useful support treatment in patients with heart failure and anemia. In: Materials of 5th International Multidisciplinary Course on Iron Anemia. Florence, Italy. March 31-April 1, 2017.

4. Zakhidova K.Kh. Vybor optimal'noi terapii pri korrektsii anemicheskogo sindroma u bol'nykh s khronicheskoi serdechnoi nedostatochnost'yu. Kardiologiya. 2018; 58(1): 25-31. (in Russian)

5. Stuklov N.I. Defitsit zheleza i anemiya u bol'nykh khronicheskoi serdechnoi nedostatochnost'yu. Ratsion. farmakoterapiya v kardiologii. 2017; 13(5): 651-60. (in Russian)

6. Rudakova L.E., Belyaeva Yu.B., Fatkabrarova A.M., Kozina L.E. Anemiya pri khronicheskoi serdechnoi nedostatochnosti (po dannym kardiologicheskogo otdeleniya). Teoret. i priklad. aspekty sovrem. nauki. 2014; 6(2): 128-30. (in Russian)

7. Andreichev L.A., Baleeva L.V. Anemiya khronicheskikh zabolevanii. Rus. med. zhurn. 2014; 2: 50-5. (in Russian)

8. Ebner N., Jankowska E.A., Ponikowski P., Lainscak M., Elsner S., Sliziuk V. et al. The impact of iron deficiency and anaemia on exercise capacity and outcomes in patients with chronic heart failure. Results from the studies investigating co-morbidities aggravating heart failure. Int. J. Cardiol. 2016; 205: 6-12. DOI: 10.1016/j.ijcard.2015.11.178

9. Rukavitsyn O.A. Anemiya khronicheskikh zabolevanii: otdel'nye aspekty patogeneza i puti korrektsii. Onkogematologiya. 2016; 11(1): 37-46. (in Russian)

10. Caughey M.C., Avery C.L., Ni H., Solomon S.D., Matsushita K., Wruck L.M. et al. Outcomes of patients with anemia and 
acute decompensated heart failure with preserved versus reduced ejection fraction (from the ARIC study community surveillance). Am. J. Cardiol. 2014; 114(12): 1850-4. DOI: 10.1016/j.amjcard.2014.09.024

11. Sharova E.K., Babaeva L.A., Padaryan S.S., Soseliya N.N., Lukina O.I., Mil'to A.S. Khronicheskaya serdechnaya nedostatochnost': rekomendatsii i real'naya klinicheskaya praktika. Ratsion. farmakoterapiya v kardiologii. 2016; 12(6): 631-7. (in Russian)

12. Yusuf S., Pitt B., Davis C.E., Hood W.B., Cohn J.N. Effect of enalapril on survival in patients with reduced left ventricular ejection fractions and congestive heart failure. N. Engl. J. Med. 1991; 325(5): 293302. DOI: 10.1056/NEJM199108013250501

13. Silverberg D.S., Wexler D., Blum M., Tchebiner J.Z., Sheps D., Keren G. et al. The effect of correction of anaemia in diabetics and non diabetics with severe resistant congestive heart failure and chronic renal failure by subcutaneous erythropoietin and intravenous iron. Nephrol. Dial. Transplant. 2003; 18(1): 141-6.

14. Martirosyan N.V., Tazhenova N.N., Demidov A.A. Dinamika klinicheskikh pokazatelei u bol'nykh khronicheskoi serdechnoi nedostatochnost'yu pozhilogo vozrasta $s$ anemiei $v$ zavisimosti ot lecheniya. Mezhdunar. zhurn. priklad. i fundamental. issledovanii. 2015; 12: 827-9. (in Russian)

15. Alexander M., Grumbach K., Remy L., Rowell R., Massie B.M. Congestive heart failure hospitalizations and survival in California: patterns according to race/ethnicity. Am. Heart J. 1999; 137(5): 919-27.

16. Akimova A.V., Nevskaya A.V., Milashchenko A.I., Kondrashova E.V. Osobennosti anemii khronicheskikh zabolevanii $v$ terapevticheskom statsionare. Vestn. ural. med. akad. nauki. 2018; 15(1): 5-11. (in Russian)

17. Kalra P.R., Collier T., Cowie M.R., Fox K.F., Wood D.A., PooleWilson P.A. et al. Haemoglobin concentration and prognosis in new cases of heart failure. Lancet. 2003; 362(9379): 211-2. DOI: 10.1016/S01406736(03)13912-8

18. Ezekowitz J.A., McAlister F.A., Armstrong P.W. Anemia is common in heart failure and is associated with poor outcomes: insights from a cohortof 12065 patients with newาonset heart failure. Circulation. 2003; 107(2): 223-5.

19. Ivanov V.P., Kolesnik M.O., Kolesnik O.M., Ivanova E.I. Osoblivosti perebigu khronichnoï sertsevoï nedostatnosti z komorbidnim zalizodefitsitom, klinikoprognostichne znachennya korektsiï zalizodefitsitu Kardiologiya: ot nauki k praktike. 2015; 3(16): 61-85. (in Ukrainian)

20. Arutyunov G.P. Anemiya u bol'nykh s KhSN. Zhurn. Serdech. Nedostatochnost'. 2003; 5: 224-8. (in Russian)

21. Nemeth E., Preza G.C., Jung C.L., Kaplan J., Waring A.J., Ganz T. The N-terminus of hepcidin is essential for its interaction with ferroportin: structure-functionstudy. Blood. 2006; 107(1): 328-33. DOI: 10.1182/blood-2005-05-2049

22. Shcherbinina S.P., Levina A.A., Lisovskaya I.L., Attaullakhanov F.I. Deistvie ekzogennykh antioksidantov na antiokislitel'nyi status eritrotsitov i uroven' gepsidina v krovi bol'nykh s narusheniyami regulyatsii metabolizma zheleza. Biomed. khimiya. 2013; 6: 710-8. (in Russian

23. Ganz T. Hepcidin in iron metabolism. Curr. Opin. Hematol. 2004; 11(4): 251-4.

24. Meshcheryakova L.M., Levina M.M., Tsybul'skaya A.A., Tret'yakov A.A., Suvorova N.N Osobennosti pokazatelei obmena zheleza (gepsidina, ferritina, HIF) pri smeshannykh anemiyakh. $V$ sb. nauch. trudov: Tendentsii razvitiya nauki i 
obrazovaniya. Po materialam XXVII mezhdunar. nauch.-prakt. konferentsii. Samara, 30 iyunya 2017 g. Samara: LZhurnal; 2017. Chast' 1. (in Russian)

25. Khrutskaya M.S. Kliniko-patogeneticheskie aspekty anemicheskogo sindroma u patsientov s khronicheskoi serdechnoi nedostatochnost'yu. V pomoshch' praktich. vrachu. 2014; 3: 134-8. (in Russian)

26. Bugrova I.A., Kalyuta T.Yu., Korsunova E.N., Shvarts Yu.G. Otkloneniya pokazatelei krasnoi krovi u patsientov s serdechnososudistymi zabolevaniyami epidemiologiya, prognoz $\mathrm{i}$ podkhody $\mathrm{k}$ lecheniyu. Kardiovaskulyar. terapiya i profilaktika. 2014; 13(6): 62-7. (in Russian)

27. Kravchun P.G., Efremova O.A., Ryndina N.G., Titova A.Yu. Struktura anemicheskogo sindroma i osobennosti trofologicheskogo statusa $\mathrm{u}$ bol'nykh $\mathrm{s}$ khronicheskoi serdechnoi nedostatochnost'yu i khronicheskoi bolezn'yu pochek. Nauch. vedomosti BelGU. 2013; 11(154): 102-6. (in Russian)

28. Matsumoto M., Tsujino T., Lee-Kawabata M., Naito Y., Akahori H., Sakoda T. et al. Iron regulatory hormone hepcidin decreases in chronic heart failure patients with anemia. Circ. J. 2010; 74(2): 301-6.

29. Enjuanes C., Klip I.T., Bruguera J., Cladellas M., Ponikowski P., Banasiak W. et al. Iron deficiency and health-related quality of life in chronic heart failure: results from a multicenterEuropean study. Int. J. Cardiol. 2014; 174(2): 268-75. DOI: 10.1016/j.ijcard.2014.03.169

30. Enjuanes C., Bruguera J., Grau M., Cladellas M., Gonzalez G., Meroño O. et al. Iron status in chronic heart failure: impact on symptoms, functional class and submaximal exercise capacity. Rev. Esp. Cardiol. (Engl. ed.). 2016; 69(3): 247-55. DOI: 10.1016/j.rec.2015.08.018 